\title{
A New G-6-PD Variant Associated with Chronic Non-spherocytic Haemolytic Anaemia in a Negro Family*
}

\author{
ELIZABETH B. HOWELL, ALVIN J. NELSON, and OLIVER W. JONES
}

From the Department of Medicine, University of California, San Diego, USA

Glucose-6-phosphate dehydrogenase deficiency is a well documented, sex-linked genetic disorder of the human population (World Health Organization, 1967). The enzyme defect may be clinically associated with drug-induced haemolytic anaemia (Beutler, 1959), favism (Zinkham, Lenhard, and Childs, 1958), or chronic non-spherocytic haemolytic anaemia (Kirkman and Riley, 1961). Of the many G-6-PD variants associated with chronic nonspherocytic haemolytic anaemia (CNSHA) all but one have been reported in Caucasian subjects (Grossman et al, 1966). This communication describes G-6-PD San Diego, a new variant found in a Negro child with CNSHA.

\section{Methods}

G-6-PD purification, determination of enzyme activity, starch gel electrophoresis, and kinetic studies (heat stability, Michaelis constant) were carried out according to the methods described by the World Health Organization (1967). pH optima were determined by the method of Beutler, Mathai, and Smith (1968). G-6-PD was electrophoresed on polyacrylamide gel following a method previously described by Levin (1967). Erythrocytes were assayed for glutathione (Beutler, Duron, and Kelly, 1963); 6-phosphogluconic dehydrogenase and glutathione reductase (Brewer, 1969); glutathione peroxidase (Necheles, Boles, and Allen, 1968); pyruvate kinase (Tanaka, 1969); triosephosphate isomerase (Schneider, 1969); glucose phosphate isomerase (Baughan et al, 1968); and hexokinase (Valentine et al, 1967).

One unit of G-6-PD activity was considered as that amount of enzyme needed to reduce $1 \mu$ mole NADP per minute at $25^{\circ} \mathrm{C}$. Partially purified enzyme preparations were stored as $70 \%$ ammonium sulphate suspensions at $4^{\circ} \mathrm{C}$ and were generally used within 3 weeks of their purification. Immediately before use, the

Received 10 January 1972.

* The work was aided by a grant from American Cancer Society NP-35A-Jones, The National Foundation-March of Dimes, and USPHS Research Grant GM 16606-03. suspensions were dialysed as previously described (World Health Organization, 1967). Enzyme preparations were adjusted to the same concentration for electrophoresis. All spectrophotometric assays were read on a Gilford Model 2400 spectrophotometer using a one centimetre light path. Tracings of stained polyacrylamide and starch gels were made on a Photovolt Densicord recording densitometer.

\section{Case Report}

The propositus (II.1), a 5-year-old Negro male, was admitted to the hospital with severe anaemia. He was anaemic at birth, required hospitalization several times during his first year, and has received between 8 and 10 blood transfusions in the subsequent years. $\mathrm{He}$ has never received any of the drugs known to cause red cell haemolysis. None of the immediate family has haematologic problems. A maternal aunt is anaemic and a maternal male cousin died of severe anaemia at birth.

Physical examination of the propositus showed an alert child in no acute distress but with pale skin, pale conjunctiva, and an enlarged spleen. A blood smear showed no spherocytes or sickled cells. Clinical laboratory data included a haemoglobin value of $7.5 \mathrm{~g} \%$, a hematocrit of $24 \%$, WBC count of 6300 with a normal differential, a reticulocyte count of $22.2 \%$, a total serum protein of $5.9 \mathrm{~g} \%$, and a total serum bilirubin of 5.8 (indirect 3.4). The level of glutathione was normal. Coombs antiglobulin in test was negative. By ${ }^{51} \mathrm{Cr}$ labelling methods, the red cells were found to have a half life of 18.8 days and scanning showed no splenic sequestration. Haemoglobin electrophoresis revealed haemoglobin $\mathrm{A}$ with normal amounts of haemoglobin $\mathrm{A}_{2}$ and $3.4 \%$ fetal haemoglobin. Heinz bodies were not seen and osmotic fragility studies were normal. Results of autohaemolysis testing revealed $2 \%$ haemolysis after 48 hours and no protection from glucose or ATP.

\section{Results}

G-6-PD Alleles in the Kindred. Erythrocyte G-6-PD activity of the kindred is presented in Figure 1. All family members have lower than 
TABLE I

PURIFICATION OF G-6-PD IN THE PROPOSITUS

\begin{tabular}{l|c|c|c|c|c}
\hline & $\begin{array}{c}\text { Volume } \\
(\mathrm{ml})\end{array}$ & $\begin{array}{c}\text { G-6-PD } \\
\text { (units/ml) }\end{array}$ & $\begin{array}{c}\text { Protein } \\
(\mathrm{mg} / \mathrm{ml})\end{array}$ & $\begin{array}{c}\text { Specific Activity } \\
\text { (units/mg) }\end{array}$ & Yield \\
\cline { 2 - 5 } & 30 & 0.028 & $35 \cdot 0$ & 0.0008 & $100 \%$ \\
DE Hemolysate & 38 & 0.024 & 0.4 & 0.0600 & $109 \% \%$ \\
$70 \%\left(\mathrm{NH}_{4}\right)_{2} \mathrm{SO}_{4}$ fraction & 8 & 0.097 & $2 \cdot 0$ & 0.0485 & $92 \%$ \\
$30 \%\left(\mathrm{NH}_{4}\right)_{2} \mathrm{SO}_{4}$ fraction & 1.4 & 0.403 & 3.8 & 0.1061 & $67 \%$ \\
\hline
\end{tabular}

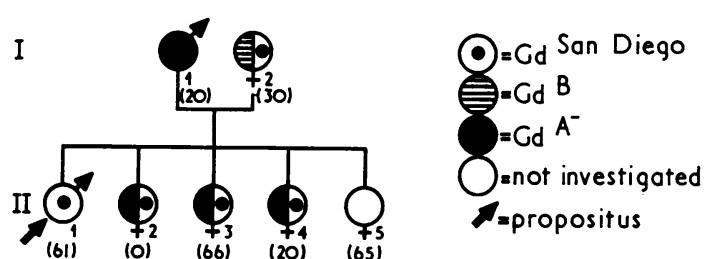

FIG. 1. Family pedigree. Erythrocyte G-6-PD activity in units/ $100 \mathrm{ml} \mathrm{RBC}$ are indicated in parentheses.

normal activity (normal activity in red cells considered as over 100 units per $100 \mathrm{ml}$ packed $\mathrm{RBC}$ ). The partially purified enzyme from the father (I.1) was characterized as G-6-PD A- . Table I summarizes a typical enzyme purification of erythrocyte G-6-PD obtained from the propositus.

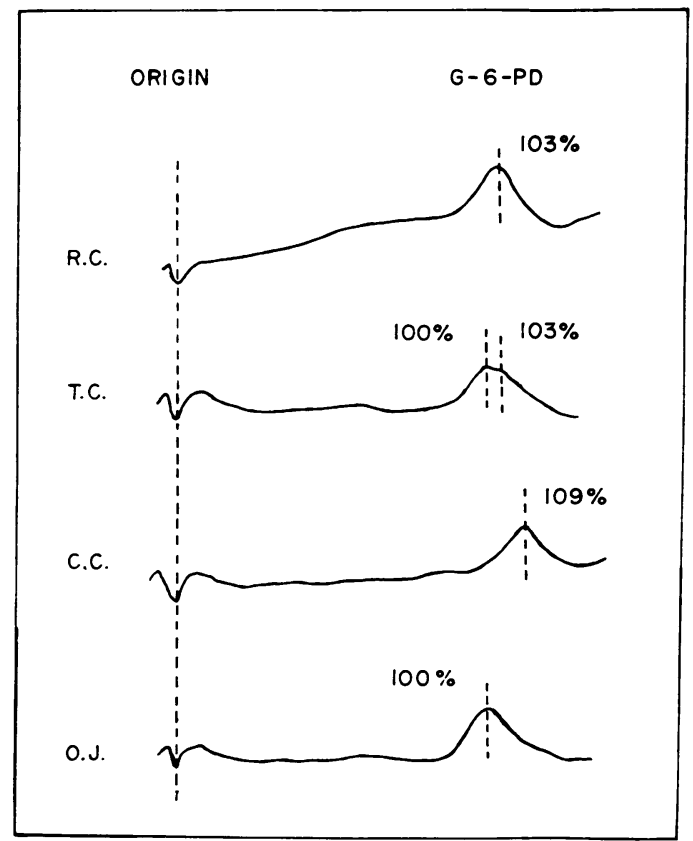

Fig. 2. Densitometer tracings of stained starch gel strips. Samples contained $0.05-0.10$ units/ml of purified G-6-PD. Bromphenol blue was used as marker. Migration of enzyme expressed as percent of normal B migration.

R.C. = propositus; T.C. $=$ mother of propositus; C.C. $=$ father of propositus; O.J. = normal control
Electrophoresis. On starch gel (Fig. 2) the partially purified G-6-PD from the propositus migrated as a distinct band similar in appearance, but slightly faster $(103 \%)$ than the normal B (one of the authors, O. J.: $100 \%$ ). The $\mathrm{A}^{-}$mutant of the father also appeared as a sharp band, but migrated considerably faster $(109 \%)$ than the normal B. Purified G-6-PD from the mother (I.2) moved as a broad flat peak, which is thought to be 2 closely migrating bands, B (100\%) and G-6-PD San Diego (propositus 103\%).

Although it is not a standard method of electrophoresis for G-6-PD, polyacrylamide gel provided another method of distinguishing G-6-PD San Diego from G-6-PD B and $A^{-}$. The results are shown in Figure 3. The enzyme of the propositus migrated slightly faster than B (O.J.); the mother's enzyme appeared as 2 forms, $B$ and that of the propositus. The G-6-PD $A^{-}$of the father migrated faster than B but slower than G-6-PD San Diego (propositus). A sister (II.2) of the propositus, was shown to be heterozygous for G-6-PD San Diego and G-6-PD A-.

Kinetic characteristics. The Michaelis constant for glucose-6-phosphate of the partially purified enzyme of the propositus was $45 \mu \mathrm{M}$, falling within normal limits. Utilization of the analogue 2deoxyglucose-6-phosphate was $2 \cdot 2 \%$ of that of glucose-6-phosphate.

Stability. The enzyme of the propositus was relatively stable when stored as a $70 \%$ ammonium sulphate suspension at $4^{\circ} \mathrm{C} ; 50 \%$ activity remained after 9 months of storage. However, as much as $80 \%$ of the enzyme was lost after dialysis for 4 hours at $4^{\circ} \mathrm{C}$. Once dialysed, G-6-PD San Diego was relatively stable to heat, losing only $12 \%$ of its activity after 20 minutes at $42^{\circ} \mathrm{C}$, whereas normal G-6-PD B lost $48 \%$ of its activity. Figure 4 shows the results of the heat stability study, following the WHO procedure (1967). At $37^{\circ} \mathrm{C}$, the normal and propositus' enzyme behaved similarly, the activities remaining relatively constant at the temperatures tested. A mixture of the 2 enzymes also remained stable. 


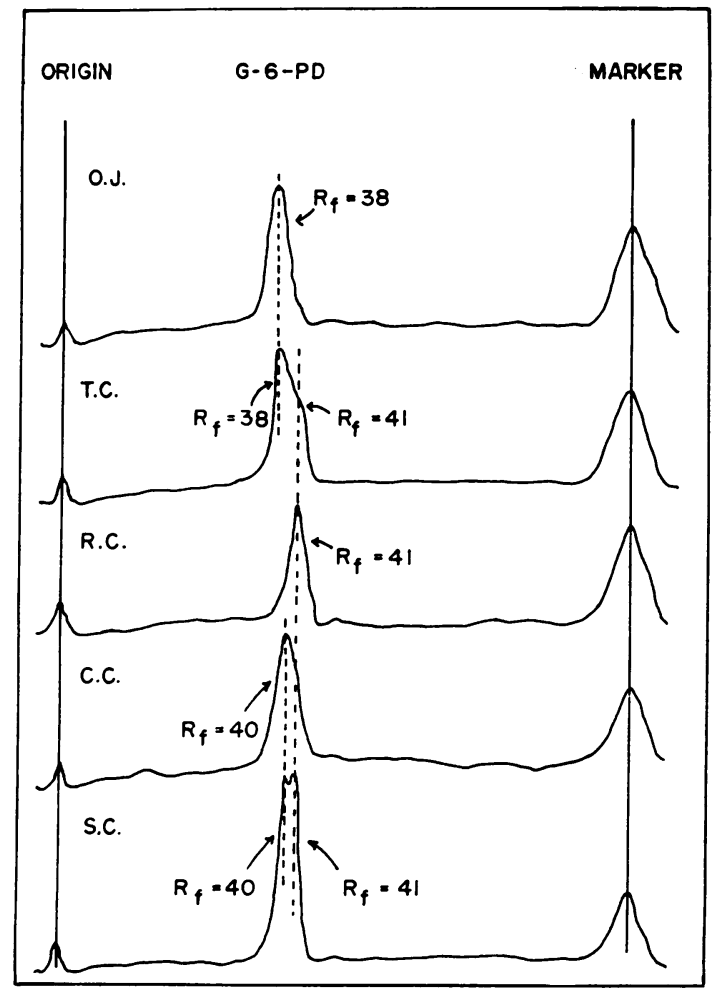

FIG. 3. Densitometer tracings of stained polyacrylamide disc gels. Samples $(0.01 \mathrm{ml})$ contained $0.05-0.10$ units $/ \mathrm{ml}$ of purified G-6-PD. Bromphenol blue was used as marker. Migration expressed as $R_{f}$ value.

O.J. = normal control; T.C. = mother of propositus; R.C. = propositus; C.C. $=$ father of propositus; S.C. $=$ sister (II.2) of propositus.

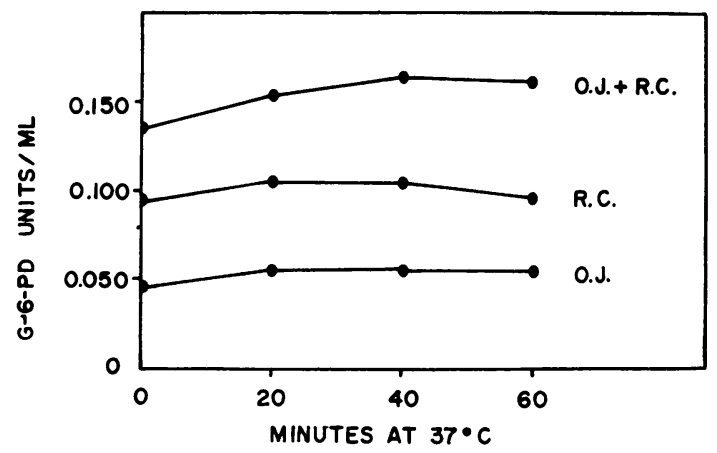

Frg. 4. Thermal stability. The effects of incubation at $37^{\circ} \mathrm{C}$ on partially purified G-6-PD following the WHO procedure (1967).

R.C. = propositus; O.J. = normal control.

$\mathrm{pH}$ Optimum. The partially purified G-6-PD from the propositus and from the mother, both have a $p \mathrm{H}$ optimum from $p \mathrm{H} \mathrm{8-9}$ consistent with the $p \mathrm{H}$ optimum for normal $\mathrm{B}$.
Enzymes of the Embden-Meyerhof and Hexosemonophosphate Shunt Pathways. Because other enzymatic defects are associated with chronic non-spherocytic haemolytic anaemia, the following enzymes were assayed in erythrocytes from the propositus: 6-phosphogluconic dehydrogenase, glutathione reductase, glutathione peroxidase pyruvate kinase, triosephosphate isomerase, glucose phosphate isomerase, and hexokinase. All were found to be within normal limits.

\section{Discussion}

Congenital non-spherocytic haemolytic disease may be associated with deficiencies of several erythrocyte enzymes. In the patient reported in this paper, the only tested enzyme found to be abnormal was glucose-6-phosphate dehydrogenase. Further study of the enzyme showed it to be not only deficient in activity but also different in some physical properties from normal G-6-PD and from the other variants previously described. Table II compares some characteristics of G-6-PD San Diego with those of other electrophoretic variants associated with CNSHA. This comparison would indicate that G-6-PD San Diego is a new and distinct variant.

The most distinctive features of G-6-PD San Diego are the low red cell activity ( $40 \%$ of normal), the fast electrophoretic mobility ( $103 \%$ of normal), its relative stability after dialysis, and its presence in a Negro individual with CNSHA. Of the other reported variants, the present case is most similar to the one other case of CNSHA described in a Negro subject (Grossman et al, 1966). However, in the previously described case, the electrophoretic mobility is slightly slower, the Michaelis constant is much higher, and the stability is much less.

In studying the other family members, it was apparent from enzyme assays and electrophoresis that the following pattern exists (see Fig. 1). The father carries the $\mathrm{Gd}^{\mathrm{A}}$ - gene, the mother is heterozygous for normal $\mathrm{Gd}^{\mathrm{B}}$ and for the variant $\mathrm{Gd}^{\text {San Diego }}$, the propositus has the $\mathrm{X}$-linked $\mathrm{Gd}^{\text {San Diego }}$ from his mother and of the 4 female sibs, at least 3 are heterozygous for $\mathrm{Gd}^{\text {San Diego }}$ and $\mathrm{Gd}^{\mathrm{A}-}$. All the children have lower than normal red cell G-6-PD activity but none except the propositus has haemolytic anaemia.

In terms of G-6-PD activity in erythrocytes, there was considerable variation in enzyme activity not only in periodic samples from the proband but in the heterozygotes as well. The enzyme activity of the propositus ranged from 20-60 units per 
TABLE II

ELECTROPHORETIC VARIANTS OF G-6-PD ASSOCIATED WITH CHRONIC NON-SPHEROCYTIC HAEMOLYTIC ANAEMIA

\begin{tabular}{|c|c|c|c|c|c|c|}
\hline Reference & $\begin{array}{c}\text { Red Cell } \\
\text { Activity } \\
\text { ( } \% \text { of } \\
\text { normal) }\end{array}$ & $\begin{array}{c}\text { Electrophoretic } \\
\text { Mobility } \\
\text { in Tris-Glycine } \\
\text { Starch Gel } \\
(\% \text { of normal })\end{array}$ & $\begin{array}{l}\mathrm{Km} \\
\underset{(\mu \mathrm{M})}{ }\end{array}$ & Thermal Stability & $\begin{array}{c}\text { Utilization } \\
\text { U\% G6P })\end{array}$ & pH Optima \\
\hline Normal (World Health Organization, 1967) & 100 & 100 & $40-60$ & Normal & $<4$ & I Truncate \\
\hline San Diego (present study) & $20-40$ & 103 & 45 & Normal & $2 \cdot 2$ & $8-9$ \\
\hline Ohio (Pinto et al, 1966) & $2-16$ & 110 & $\uparrow$ & Labile & $<4$ & $?$ \\
\hline Torrance (Tanaka and Beutler, 1969) & $<1$ & $\begin{array}{c}\text { Not visible in } \\
\text { Tris-glycine }\end{array}$ & $40-60$ & Labile & $2 \cdot 4$ & 6.5 \\
\hline Beaujon (Boivin and Galand, 1968) & 0 & Fast & 182 & $?$ & $?$ & $9 \cdot 5$ \\
\hline Milwaukee (Westring and Pisciotta, 1966) & $<1$ & 92 & 224 & $?$ & 3 & $8 \cdot 0$ \\
\hline 'Chicago II' (Grossman et al, 1966) & 0 & 104 & 188 & Labile & $?$ & $9 \cdot 0$ \\
\hline Worcester (Snyder et al, 1970) & 0 & $\begin{array}{l}\text { Not done in } \\
\text { Tris-glycine }\end{array}$ & 61 & Labile & $<1$ & ? \\
\hline Tripler (Engstrom and Beutler, 1970) & 40 & $\begin{array}{l}\text { Not done in } \\
\text { Tris-glycine }\end{array}$ & 30 & Labile & $3 \cdot 7$ & Normal \\
\hline Fulham (Huskisson et al, 1970) & 100 & 71 & 123 & ? & ? & ? \\
\hline Alhambra (Beutler and Rosen, 1970) & $10-25$ & 95 & 55 & Labile & 2 & Normal \\
\hline Ramat-Gan (Ramot et al, 1969) & 0 & - & 35 & Labile & 40 & 6.5 and 10 \\
\hline Bat-Yam (Ramot et al, 1969) & 0 & - & 27 & Labile & 40 & 6.5 and 10 \\
\hline Ashdod (Ramot et al, 1969) & $<10$ & - & 100 & Relatively stable & 40 & 6.5 and 10 \\
\hline Frieburg (Busch and Boie, 1970) & $10-20$ & $\begin{array}{l}\text { Not done in } \\
\text { Tris-glycine }\end{array}$ & $87-118$ & $?$ & $?$ & Biphasic \\
\hline Rotterdam (Rattazzi et al, 1971) & 1.9 & 95 & 23 & Normal & 6 & 7 and 9.5 \\
\hline
\end{tabular}

$100 \mathrm{ml}$ of packed erythrocytes. Much of the variation we can attribute to the significant number of reticulocytes present. One of the female sibs (II.2) of the propositus consistently had very low G-6-PD activity ranging from 0 to 10 units yet had no evidence of haemolytic disease. Thus it appears that the mutant allele, G-6-PD, San Diego, when present in a hemizygous form, is associated with CNSHA. Females in this family are protected from CNSHA if they are heterozygous for G-6-PD San Diego and either the normal $B$ allele or the $A^{-}$ variant regardless of the level of G-6-PD activity in their erythrocytes.

We must conclude in this family that the new G-6-PD mutation alone results in a chronic haemolytic disease, even when the enzyme activity is 20 $40 \%$ of normal.

\section{Summary}

A new G-6-PD variant associated with congenital non-spherocytic haemolytic anaemia in a Negro subject is described. This variant is unique in that it has a fast electrophoretic mobility, low red cell activity, and relative stability after dialysis.
Michaelis constant for G-6-P, $p \mathrm{H}$ optimum, and G-6-P substrate utilization are normal. These characteristics distinguish this variant, G-6-PD San Diego, from previously described variants associated with congenital non-spherocytic haemolytic anaemia.

\section{REFERENCES}

Baughan, M. A., Valentine, W. N., Paglia, D. E., Ways, P. O. Simons, E. R., and DeMarsh, Q. B. (1968). Hereditary hemolytic anemia associated with glucosephosphate isomerase (GPI) deficiency-a new enzyme defect of human erythrocytes. Blood, 32, 236-249.

Beutler, E. (1959). The hemolytic effect of Primaquine and related compounds: a review. Blood, 14, 103-139.

Beutler, E., Duron, O., and Kelly, B. M. (1963). Improved method for the determination of blood glutathione. Fournal of Laboratory and Clinical Medicine, 61, 882-888.

Beutler, E., Mathai, C. K., and Smith, J. E. (1968). Biochemical variants of glucose-6-phosphate dehydrogenase giving rise to congenital nonspherocytic hemolytic disease. Blood, 31, 131-150.

Beutler, E. and Rosen, R. (1970). Nonspherocytic congenital hemolytic anemia due to a new G-6-PD variant: G-6-PD Alhambra. Pediatrics, 45, 230-235.

Boivin, P. and Galand, C. (1968). Nouvelles variantes de la glucose-6-phosphate déhydrogénase érythrocytaire. Revue Francaise d'Etudes Cliniques et Biologiques, 13, 30-39.

Brewer, G. J. (1969). 6-Phosphogluconate dehydrogenase and glutathione reductase. In Biochemical Methods in Red Cell Genetics, edited by J. J. Yunis, pp. 139-155. Academic Press, New York. 
Busch, D. and Boie, K. (1970). Glucose-6-Phosphat-Dehydrogenase-Defekt in Deutschland. II. Eigenschaften des Enzyms (Typ Freiburg). Klinische Wochenschrift, 48, 74-78.

Engstrom, P. F. and Beutler, E. (1970). G-6-PD Tripler: A unique variant associated with chronic hemolytic disease. Blood, 36, 10-13.

Grossman, A., Ramanathan, K., Justice, P., Gordon, J., Shahidi, N. T., and Hsia, D. (1966). Congenital nonspherocytic hemolytic anemia associated with erythrocyte glucose-6-phosphate dehydrogenase deficiency in a Negro family. Pediatrics, 37, 624 629.

Huskisson, E. C., Murphy, B., and West, C. (1970). Glucose-6phosphate dehydrogenase deficiency and chronic haemolysis in an English family. Fournal of Clinical Pathology, 23, 135-139.

Kirkman, H. N. and Riley, H. D., Jr. (1961). Congenital nonspherocytic hemolytic anemia. American fournal of Diseases of Children, 102, 313-320.

Kirkman, H. N., Rosenthal, I. M., Simon, E. R., Carson, P. E., and Brinson, A. G. (1964). 'Chicago I' variant of glucose-6-phosphate dehydrogenase in congenital hemolytic disease. fournal of Laboratory and Clinical Medicine, 63, 715-725.

Levin, F. B. (1967). Razdelenie i vyyavlenie izozimov glyukozo-6fosfatdegidrogenazy kletok linii J-96 s pomoshch' yu èlektroforeza no poliakrilamidnom gele. Voprosy Meditsinkoi Khimii, 13, 556-557.

Necheles, T. F., Boles, T. A., and Allen, D. M. (1968). Erthrocyte glutathione peroxidase deficiency and hemolytic disease of the newborn infant. Fournal of Pediatrics, 72, 319-324.

Pinto, P. V. C., Newton, W. A., Jr., and Richardson, K. E. (1966). Evidence for four types of erythrocyte glucose-6-phosphate dehydrogenase from G-6-PD deficient human subjects. Fournal of Clinical Investigation, 45, 823-831.

Ramot, B., Ben-Bassat, I., and Shchory, M. (1969). New glucose-6phosphate dehydrogenase variants observed in Israel and their association with congenital non-spherocytic hemolytic disease. fournal of Laboratory and Clinical Medicine, 74, 895-901.

Rattazzi, M., Corash, L., Zanen, G. van, Jaffe, E., and Piomelli, S. (1971). G6PD deficiency and chronic hemolysis: four new mutants-relationships between clinical syndrome and enzyme kinetics. Blood, 38, 205-218.

Schneider, A. S. (1969). Triosephosphate isomerase deficiency. In Biochemical Methods in Red Cell Genetics, edited by J. J. Yunis, pp. 189-200. Academic Press, New York.

Snyder, L. M., Necheles, T. F., and Reddy, W. J. (1970). G-6-PD Worcester. A new variant associated with $\mathrm{X}$-linked optic atrophy. American fournal of Medicine, 49, 125-132.

Tanaka, K. R. (1969). Pyruvate kinase. In Biochemical Methods in Red Cell Genetics, edited by J. J. Yunis, pp. 167-188. Academic Press, New York.

Tanaka, K. R. and Beutler, E. (1969). Hereditary hemolytic anemia due to glucose-6-phosphate dehydrogenase Torrance: a new variant. fournal of Laboratory and Clinical Medicine, 73, 657-667.

Valentine, W. N., Oski, F. A., Paglia, D. E., Baughan, M. A., Schneider, A. S., and Naiman, J. L. (1967). Hereditary hemolytic anemia with hexokinase deficiency. New England fournal of Medicine, 276, 1-11.

Westring, D. W. and Pisciotta, A. V. (1966). Anemia, cataracts and seizures in patients with glucose-6-phosphate dehydrogenase deficiency. Archives of Internal Medicine, 118, 385-390.

World Health Organization (1967). Standardization of procedures for the study of glucose-6-phosphate dehydrogenase. WHO Technical Report Series, No. 366.

Zinkham, W. H., Lenhard, R. E., Jr., and Childs, B. (1958). A deficiency of glucose-6-phosphate dehydrogenase activity in erythrocytes from patients with favism. Bulletin of the fohns Hopkins Hospital, 102, 169-175. 